Care: Jurnal Ilmiah Ilmu Kesehatan Vol .8, No.1, 2020, hal 1-11

Tersedia online di https://jurnal.unitri.ac.id/index.php/care

ISSN 2527-8487 (online)

ISSN 2089-4503 (cetak)

\title{
FAKTOR YANG MEMPENGARUHI KLB CAMPAK ANAK USIA SEKOLAH DASAR
}

\author{
Ferry Ardhiansyah ${ }^{1)}$, Kamilah Budhi R. ${ }^{2}$, Ari Suwondo ${ }^{3)}$ \\ ${ }^{1)}$ Magister Epidemiologi Sekolah Pascasarjana Universitas Diponegoro Semarang \\ ${ }^{2)}$ Bagian Ilmu Kesehatan Anak Rumah Sakit Umum Pusat dr.Kariadi Semarang \\ ${ }^{3}$ Program Pascasarjana Politeknik Kesehatan Kemenkes Semarang \\ E-mail :verie@ymail.com
}

\begin{abstract}
Measles is a very contagious disease and still a health problem in Indonesia. Immunization coverage of measles BIAS in Pesawaran District is quite good (98.8\%), but the incidence measles outbreaks in elementary school-age children still occur, this can be caused by various child factors, maternal and environmental factors. The purpose to examine the factors that influence outbreaks of measles are children of primary school age. The observational analytics study design with a mix methods approach. The participants consist of 27 cases and 54 controls, in-depth interviews with UKS teachers. Bivariate using Chi Square test and multivariate analysis using logistic regression test. The result of bivariate analysis showed that there was a correlation between contact history $(p=0,001)$, maternal age $(p=0,009)$, occupancy density $(p=0,023)$ with the incidence of measles outbreaks of primary school age children. Logistic regression test showed the significance value of contact history $(p=0,024)$, occupancy density $(p=0,036)$, The result of in-depth interviews UKS teacher knowledge about measles is good. Conclusion of the factors that influence the incidence of measles outbreaks of primary school age children is a bistory of contact and occupany density with probability 83,25\%. This research needs to be continued by examining other risk factors such as nutritional status, areas prone to outbreaks and implementation of the Clean and Healthy Behavior Program (PHBS) in schools.
\end{abstract}

Keywords : Chidren of primary school age; measles outbreak; contact history.

\begin{abstract}
ABSTRAK
Penyakit campak merupakan penyakit yang sangat menular dan masih menjadi masalah kesehatan di Indonesia. Cakupan imunisasi BIAS campak di Kabupaten Pesawaran sudah cukup baik (98\%), namun peristiwa KLB campak pada anak usia sekolah dasar masih terjadi, hal ini dapat disebabkan oleh berbagai faktor anak, ibu dan lingkungan. Tujuan meneliti faktor yang mempengaruhi KLB campak anak usia sekolah dasar. Desain penelitian observasional analitik, dengan rancangan studi mix methods yaitu case control dan indepth interview. Jumlah kasus 27 dan kontrol 54, wawancara mendalam dilakukan pada keluarga dan guru UKS. Analisis secara bivariat menggunakan uji Chi Square dan multivariat menggunakan uji regresi logistik. Hasil anaisis bivariat menunjukkan ada hubungan riwayat kontak $(p=0,001)$, umur ibu $(p=0,009)$, kepadatan hunian $(p=0,023)$ dengan kejadian KLB
\end{abstract}

Cara mengutip: Ardhiansyah, Ferry., Budhi, R. Kamilah., \& Suwondo, Ari. (2020). Faktor yang Mempengaruhi KLB Campak Anak Usia Sekolah Dasar. Care:Jurnal Ilmiah Ilmu Kesehatan, 8(1), 1-11 
anak usia sekolah dasar. Uji regresi logistik menunjukkan nilai signifikansi riwayat kontak $(p=0,024)$, kepadatan hunian $(p=0,036)$ hasil wawancara mendalam pengetahuan guru UKS tentang penyakit campak baik. Kesimpulan faktor yang mempengaruhi kejadian KLB campak anak usia sekolah dasar adalah riwayat kontak dan kepadatan hunian dengan probabilitas $83,25 \%$. Penelitian ini perlu dilanjutkan dengan meneliti faktor risiko lain seperti status gizi, daerah rawan KLB dan pelaksanan progra Perilaku Hidup Bersih dan Sehat (PHBS) di sekolah.

Kata Kunci : Anak usia sekolah dasar; KLB campak; riwayat kontak.

\section{PENDAHULUAN}

Penyakit campak adalah suatu penyakit yang sangat menular yang disebabkan oleh virus campak. (CHIN, 2000) Campak merupakan salah satu Penyakit yang Dapat Dicegah Dengan Imunisasi (PD3I), dan masih menjadi masalah kesehatan di Indonesia.(Setiawan, 2008) Penyakit campak terutama menyerang anak usia kurang 5 tahun dengan gejala klinis berupa panas mendadak disusul dengan timbulnya ruam (rash) mulai dari belakang telinga menyebar keseluruh tubuh. Pada anak dengan status gizi kurang dapat terjadi infeksi sekunder berupa pneumonia, diare, encephalitis dan otitis media, yang dapat menyebabkan kematian.(Center of Disease Control and Prevention (CDC), 2018)

Virus campak termasuk famili paramyxovirus genus morbillivirus yang berukuran diameter 140 milimikron virus morbili sangat peka terhadap temperatur.
Pada suhu kamar virus bertahan hidup selama 3-4 jam, penularan melalui saluran napas, menyebar lewat udara masuk ketubuh dan tidak memerlukan jumlah virus yang banyak untuk menginfeksi orang yang rentan terhadap penyakit (Widagdo, 2011). Semakin banyak virus masuk kekelenjar limpa mengakibatkan terjadinya viremia primer menyebar keberbagai jaringan dan organ limfoid, termasuk kulit, ginjal, saluran cerna dan hati.(Setiawan, 2008)

Sebanyak 90\% dari anak yang kontak dengan penderita campak akan terkena infeksi (Widagdo, 2011). Penyakit campak masih merupakan penyebab kematian bayi dan anak dinegara berkembang dan juga terus berjangkit di negara maju.(Center of Disease Control and Prevention (CDC), 2018) Penyakit campak sangat berpotensi untuk menimbulkan Kejadian Luar Biasa (KLB), apabila terdapat 5 atau lebih kasus 
campak dalam waktu 4 minggu secara berturut-turut, terjadi mengelompok dan adanya hubungan epidemiologis. (Kemenkes RI, 2011).

Imunisasi merupakan proses untuk meningkatkan sistem kekebalan tubuh dengan cara memasukkan vaksin yakni virus atau bakteri yang dilemahkan, dibunuh, atau bagian-bagian dari bakteri (virus) tersebut telah dimodifikasi. (Williams, 2003) Imunisasi rutin untuk campak diberikan pada saat anak umur 912 bulan, dan imunisasi lanjutan (booster) akan diberikan pada anak usia sekolah yakni imunisasi campak satu kali pada anak kelas 1 SD atau sederajat dilaksanakan pada saat BIAS (Bulan Imunisasi Anak Sekolah), untuk melindungi anak terhadap campak selama 10 tahun setelah peberian booster. (Kemenkes RI, 2005).

Imunisasi yang telah diperoleh dari bayi belum cukup untuk melindungi terhadap penyakit, sejak anak mulai memasuki usia sekolah dasar terjadi penurunan terhadap tingkat kekebalan yang diperoleh saat bayi, pada usia sekolah anak-anak mulai berinteraksi dengan lingkungan baru dan bertemu dengan lebih banyak orang, sehingga lebih berisiko tertular atau menularkan penyakit, maka pemerintah melalui Kementerian Kesehatan Republik Indonesia melaksanakan program imunisasi pada anak sekolah, sesuai dengan Keputusan Menteri Kesehatan Republik Indonesia Nomor 1611/MENKES/SK/XI/2005 tentang pedoman penyelenggaraan imunisasi, BIAS adalah bentuk operasional dari imunisasi lanjutan pada anak sekolah yang dilaksanakan pada bulan tertentu setiap tahunnya dengan sasaran semua anak kelas 1,2 dan 3 Sekolah Dasar (SD) atau sederajat diseluruh Indonesia. (Kemenkes RI, 2005).

Menurut Profil Kesehatan Indonesia Tahun 2016, Indonesia memiliki cakupan imunisasi campak diatas target WHO (90\%) sejak tahun 2008, tahun 2016 cakupan meningkat (93,0\%), di Lampung (99,8\%), hal ini menunjukkan Lampung telah berhasil mencapai target eradikasi (95\%). Menurut Profil Kesehatan Provinsi Lampung tahun 2016 terdapat 442 kasus campak. (Dinkes Provinsi Lampung, 2017) Incidence Rate (IR) campak tahun 2016 (5,0 per 100.000 penduduk), meningkat dibanding tahun 2015 (3,20 per 100.000 penduduk). IR di Lampung lebih tinggi dibanding angka nasional sebesar 5,4 per 100.000 penduduk. Jumlah KLB campak tahun 2016 di Indonesia sebanyak 129 frekuensi 
KLB (1.511 kasus). Frekuensi KLB campak tertinggi terjadi di Sumatra Barat (33 KLB, dengan 495 kasus), dilaporkan 1 orang meninggal. Di Lampung (7 KLB dengan 58 kasus) dengan 1 kematian. (Kemenkes RI, 2017).

Cakupan imunisasi BIAS campak di Kabupaten Pesawaran tahun 2016 sudah cukup baik yakni 98,5\% dan pada tahun 2017 cakupan imunisasi BIAS campak 98,8\%, namun dari cakupan imunisasi BIAS campak yang tinggi masih sering terjadi kasus campak, hingga terjadi peristiwa KLB pada beberapa daerah di Kabupaten Pesawaran. (Dinkes Kabupaten Pesawaran, 2017)

Penelitian Casaeri menunjukkan bahwa terjadinya KLB campak disebabkan oleh faktor gizi kurang, riwayat kontak dan kepadatan hunian.(Casaeri, 2003) Studi lain di Kota Banjarmasin menunjukkan bahwa status imuniasi campak $(\mathrm{OR}=4,64)$, pendidikan ibu $(\mathrm{OR}=13,88)$, pendidikan ayah $(\mathrm{OR}=6,33)$, dan umur anak $(\mathrm{OR}=2,46)$ sebagai faktor risiko terjadinya campak.(Budi, 2012)

Hasil pengamatan Kepala Seksi Pencegahan dan Pengamatan Penyakit Dinas Kesehatan Kabupaten Pesawaran menunjukkan, kejadian KLB campak dibeberapa wilayah di Kabupaten
Pesawaran, banyak terjadi pada anak sekolah, yang sangat dipengaruhi oleh faktor sosial ekonomi, hal ini karena terdapat beberapa desa dengan aliran agama tertentu menolak untuk dilakukan imunisasi terhadap anaknya. Sehubungan dengan permasalahan diatas, maka penulis tertarik untuk mengetahui faktor anak, ibu dan lingkungan terhadap kejadian KLB anak usia sekolah dasar di Kabupaten Pesawaran Tahun 2016-2017.

\section{METODE PENELITIAN}

Desain penelitian observasional analitik, dengan rancangan studi Mix Methods, yang menggabungkan metode kuantitatif dengan metode kualitatif. (Sugiyono, 2016) Metode kuantitatif yang dipilih yaitu metode penelitian kasus kontrol untuk mengkaji hubungan antara faktor risiko dengan efek yang terjadi. Metode kualitatif dengan tehnik wawancara mendalam (indepth interview) untuk memperkuat hasil penelitian kuantitatif. Wawancara mendalam untuk mengumpulkan data berkenaan dengan reaksi subyektif dalam studi yang mungkin memiliki pengaruh terhadap hasil penelitian. (Abbas TC., Charles, 2010) Besar sampel dari penelitian ini dihitung menggunakan rumus (Lemeshow, S., David W.Hosmer Jr., 1997) : 


$$
\begin{aligned}
& P_{1}=\frac{(O R) P_{2}}{(O R) P_{2}+\left(1-P_{2}\right)} \\
& n=\frac{Z^{2}{ }_{1}-\alpha / 2\left\{1 /\left[P_{1}\left(1-P_{1}\right)\right]+1 /\left[P_{2}\left(1-P_{1}\right)\right]\right\}}{[\operatorname{In}(1-\varepsilon)]^{2}}
\end{aligned}
$$

Kasus adalah anak usia sekolah dasar yang menderita campak pada saat terjadi KLB campak, tercatat dalam laporan C1 campak yang memenuhi kriteria inklusi dan eksklusi, sedangkan kontrol adalah anak yang tidak sakit campak, merupakan tetangga kasus dengan matching umur dan jenis kelamin. Teknik pengambilan sampel dilakukan dengan purposive sampling, Jumlah kasus terdapat 27 orang dan kontrol 54 orang dengan perbandingan kasus dan kontrol 1:2, sehingga seluruh sampel berjumlah 81 orang. Informan terdiri atas informan guru UKS 3 orang. Variabel dependen pada penelitian ini adalah kejadian KLB campak anak usia sekolah dasar, sedangkan variabel independen adalah riwayat kontak dengan penderita campak, umur ibu, pendidikan ibu, kepadatan hunian, dan pengetahuan guru UKS.

Pelaksanaan kegiatan analisis data sekunder dilakukan dengan mengumpulkan data mengenai keadaan wilayah (topografi, batas wilayah, luas wilayah masing-masing kecamatan dan jumlah desa, jumlah penduduk, Fasilitas dan sarana pelayanan kesehatan milik pemerintah dan swasta, serta Distribusi tenaga kesehatan); Gambaran responden meliputi tingkat pendidikan ibu, pekerjaan ibu, umur anak, dan jenis kelamin anak. Pengumpulan data dilakukan lewat kuesioner dan wawancara terstruktur. Kegiatan pelaksanaan penelitian yaitu pengambilan data yang dibutuhkan sesuai dengan tahapan penelitian yang telah disusun, antara lain: periksa kesiapan penelitian, pemilihan responden dan informan penelitian, pelaksanaan penelitian dengan mengukur variabel menggunakan kuesioner dan observasi, pelaksanaan penelitian dengan melakukan wawancara mendalam terhadap informan penelitian.

Data yang diperoleh dianalisis secara statistik dengan analisis univariat untuk menjelaskan distribusi frekuensi, analisis bivariat dengan menggunakan uji Chi Square dan analisis multivariat regresi logistik ganda metode backward conditional dengan tingkat signifikansi yang ditetapkan adalah 0,05. Penelitian dilaksanakan pada bulan Oktober sampai dengan Desember 2018 pada puskesmas di wilayah kerja Dinas Kesehatan Kabupaten Pesawaran yang terjadi KLB campak. Penelitian ini telah ditinjau dan telah mendapatkan persetujuan dari Komite Etik Penelitian Kesehatan (KEPK) Fakultas Kedokteran Universitas 
Diponegoro Semarang, Ethical Clereance Nomor 611/EC/FK-UNDIP/X/2018.

\section{HASIL}

Tabel 1 menunjukkan responden mempunyai tingkat pendidikan yang tergolong rendah yaitu tamat SD yaitu sebesar 51,9\%. Ibu yang tidak bekerja atau sebagai ibu rumah tangga yaitu sebesar $74,1 \%$. Sebagian besar umur anak dari responden penelitian adalah berusia kurang dari 13 tahun sebanyak 77,8\%, Sebagian besar anak dari responden penelitian adalah berjenis kelamin perempuan sebanyak $51,9 \%$, sedangkan anak yang berjenis kelamin laki-laki sebanyak $48,1 \%$.
Tabel 1. Karakteristik Identitas Responden

\begin{tabular}{lcc}
\hline Karakteristik & f & $\mathbf{( \% )}$ \\
\hline Tingkat Pendidikan & & \\
Ibu & & \\
a. Tamat SD & 42 & 51,9 \\
b. Tamat SLTP & 23 & 28,4 \\
c. Tamat SLTA & 13 & 16,0 \\
d. Tamat Sarjana S1 & 3 & 3,7 \\
Pekerjaan Ibu & & \\
a. Buruh & 1 & 1,2 \\
b.Guru Swasta & 1 & 1,2 \\
c. Honorer & 1 & 1,2 \\
d. Ibu Rumah Tangga & 60 & 74,1 \\
e. Pegawai & 1 & 1,2 \\
f. Swasta & 1 & 1,2 \\
g. Petani & 13 & 16,0 \\
h. Wiraswasta & 3 & 3,7 \\
Umur Anak & & \\
a. $<13$ Tahun & 63 & 77,8 \\
b. 13 - 15 Tahun & 15 & 18,5 \\
c. > 15 Tahun & 3 & 3,7 \\
Jenis Kelamin Anak & & \\
a. Perempuan & 42 & 51,9 \\
b. Laki-laki & 39 & 48,1 \\
\hline
\end{tabular}

Tabel 2. Rekapitulasi Hasil Analisis Bivariat dengan uji chi square

\begin{tabular}{lccc}
\hline \multicolumn{1}{c}{ Variabel } & $\boldsymbol{P}_{\text {value }}$ & $\boldsymbol{O R}$ & $\mathbf{9 5 \%} \boldsymbol{C I}$ \\
\hline Riwayat Kontak dengan Penderita & 0,001 & 5,339 & $1,020-8,484$ \\
Umur Ibu & 0,009 & 5,950 & $1,741-47,570$ \\
Pendidikan Ibu & 0,693 & 0,795 & $0,255-2,482$ \\
Kepadatan Hunian & 0,023 & 3,382 & $1,145-9,994$ \\
\hline
\end{tabular}

Berdasarkan Tabel 2, diketahui bahwa variabel pendidikan ibu memiliki $\mathrm{p}>0,05$ sehingga hipotesis penelitian tidak terbukti dan dapat disimpulkan tidak ada hubungan bermakna antara pendidikan ibu dengan kejadian KLB campak anak usia sekolah dasar, sedangkan variabel riwayat kontak dengan penderita campak, umur ibu, dan kepadatan hunian memiliki $\mathrm{p}<0,05$, maka dapat disimpulkan bahwa hipotesis penelitian terbukti, artinya secara statistik ada hubungan bermakna antara riwayat kontak, umur ibu, dan kepadatan hunian dengan kejadian KLB campak anak usia sekolah dasar. 
Care: Jurnal Ilmiah Ilmu Kesehatan Vol .8, No.1, 2020, hal 1-11

Tabel 3. Variabel kandidat analisis Multivariat $\mathrm{p}$ value $<0,25$

\begin{tabular}{lccc}
\hline \multicolumn{1}{c}{ Variabel } & $\boldsymbol{P}$-value & $\boldsymbol{O R}$ & $\mathbf{9 5 \%} \boldsymbol{C I}$ \\
\hline Riwayat Kontak dengan Penderita & 0,001 & 5,339 & $1,841-15,484$ \\
Umur Ibu & 0,009 & 5,950 & $1,339-25,314$ \\
Kepadatan Hunian & 0,023 & 3,382 & $1,145-9,994$ \\
\hline
\end{tabular}

Berdasarkan Tabel 3 ketiga variabel kandidat sebagai faktor risiko kejadian KLB campak anak usia sekolah dasar, selanjutnya dilakukan analisis secara multivariat menggunakan regresi logistik. Karena pada penelitian ini data kuantitatif diolah menggunakan metode case control, maka dalam analisis regresi logistik digunakan metode backward conditional. Hasil analisis dengan regresi logistik diperoleh hasil seperti pada tabel 4.

Tabel 4. Hasil Analisis Multivariat

\begin{tabular}{lccccc}
\hline \multicolumn{1}{c}{ Variabel } & \multirow{2}{*}{$\mathrm{B}$} & P value & \multirow{2}{*}{ OR } & & \multicolumn{2}{c}{ 95,0\% CI for EXP $(\beta)$} \\
\cline { 5 - 7 } & & & & Lower & Upper \\
\hline Riwayat Kontak & 1,421 & 0,024 & 4,141 & 1,208 & 14,201 \\
Kepadatan Hunian & 1,379 & 0,036 & 3,971 & 1,092 & 14,443 \\
Constant & $-4,404$ & 0,000 & & & \\
\hline
\end{tabular}

Berdasarkan Tabel 4 hasil analisis merupakan faktor risiko kejadian KLB multivariat dengan uji regresi logistik campak anak usia sekolah dasar di ganda pada tingkat kemaknaan 95\% Kabupaten Pesawaran.

menunjukkan riwayat kontak dengan penderita campak dengan nilai $\mathrm{p}=0,024$; Dengan demikian probabilitas faktor $\mathrm{OR}=4,141 ; 95 \% \mathrm{CI}=1,208-14,201 \mathrm{dan}$ kepadatan hunian dengan nilai $\mathrm{p}=0,036$; risiko yang berpengaruh dapat dihitung dengan persamaan probability event $\mathrm{OR}=3,971 ; 95 \% \mathrm{CI}=1,092-14,443$

$$
\begin{aligned}
& \mathrm{P}=\frac{1}{1+e^{-\left(a+\beta 1 \times 1+\beta 2 \chi^{2}\right)}} \times 100 \% \\
& \mathrm{P}=\frac{1}{1+2,718^{-(-4,404+1,421+1,379)}} \times 100 \% \\
& \mathrm{P}=\frac{1}{1+2,718^{-(1,604)}} \times 100 \%
\end{aligned}
$$




$$
\begin{aligned}
& P=\frac{1}{1,2010} \times 100 \% \\
& P=0,8325 \times 100 \% \\
& P=83,25 \%
\end{aligned}
$$

Berdasarkan hasil perhitungan persamaan probability event di atas dapat diartikan bahwa pada anak usia sekolah dasar yang mempunyai riwayat kontak dengan penderita campak, serta tinggal dalam hunian yang padat, maka mempunyai probabilitas untuk terjadi peristiwa KLB sebesar $83,25 \%$. Hasil wawancara dengan tokoh agama di lokasi penelitian masih kurang mendukung dengan pelaksanaan imunisasi campak (BIAS), karena belum jelas bahan dan kandungan vaksin yang digunakan, serta belum dinyatakan halal oleh MUI, hal ini dikembalikan pada kepercayaan masing-masing sehingga masih ada tokoh agama yang kurang mendukung pelaksanaan imunisasi di Kabupaten Pesawaran.

\section{PEMBAHASAN}

Riwayat kontak merupakan suatu keadaan dimana seseorang pernah terpapar langsung dengan penderita campak maupun dengan lingkungan bermain, tempat tinggal ataupun tempat belajar seperti sekolah. Sekitar 90\% dari anak yang pernah kontak dengan penderita campak akan terkena infeksi (Widagdo,
2011). Penyakit campak mudah ditularkan melalui saluran pernafasan pada saat penderita batuk, bersin, atau sekresi dari pernafasan.(Center of Disease Control and Prevention (CDC), 2018) Seseorang dapat tertular melalui udara dengan cara droplet dan kontak langsung dengan penderita. (CHIN, 2000) Hasil analisis multivariat dengan uji Logistic regression diperoleh nilai $\mathrm{p}=0,024<\alpha=0,05$ maka H0 ditolak, hasil analisis membuktikan bahwa riwayat kontak dengan penderita campak berpengaruh terhadap kejadian KLB campak anak usia sekolah dasar di Kabupaten Pesawaran. Hasil Odds Ratio sebesar 4,141 dengan 95\%CI $=1,208-$ 14,201 yang berarti bahwa siswa sekolah dasar yang memiliki riwayat kontak dengan penderita campak memiliki risiko 4,141 kali untuk terjadi KLB campak dibanding dengan siswa yang tidak memiliki riwayat kontak. Hasil ini sejalan dengan penelitian Putu Dwi Adi (2012) yang menunjukkan bahwa riwayat kontak dengan penderita campak mempunyai risiko menimbulkan kejadian campak 21,12 kali dibandingkan dengan tanpa riwayat kontak dengan penderita 
campak.(Adi, 2012) Hasil wawancara mendalam terhadap guru pembina UKS menunjukkan bahwa guru UKS mengetahui tentang penyakit campak, tanda dan gejala penyebab dan penularan penyakit campak, serta pencegahan dan hal yang dilakukan guru UKS apabila ada siswa yang terserang penyakit campak, sehingga apabila terdapat siswa yang terserang campak dapat segera diperiksakan kepuskesmas dan diberi izin belajar agar penularan disekolah tidak terjadi. Hanya ada satu guru UKS tidak mengetahui tentang kejadian KLB campak dikarenakan belum semua guru UKS mendapatkan pelatihan atau penyuluhan tentang penyakit campak, sebaiknya petugas puskesmas memberikan penyuluhan lintas sektor kepada guru pembina UKS sehingga apabila terjadi KLB campak dapat segera dilaporkan kepada petugas kesehatan. Cara untuk mencegah agar tidak tertular oleh penderita campak lain dengan cara menggunakan alat pelindung diri seperti masker, hal ini disebabkan karena penularan penyakit campak melalui udara (airborne disease), serta penderita campak sebaiknya diisolasi agar tidak menularkan kepada orang lain.

Rumah merupakan kebutuhan pokok manusia sebagai tempat tinggal dan tempat berlindung dari iklim dan gangguan mahluk hidup lain. Rumah merupakan tempat untuk berkumpul anggota keluarga, bahkan bayi, anak-anak orang tua menghabiskan hampir seluruh waktunya didalam rumah. Dalam Kepmenkes nomor 829 / MENKES / SK / VII/1999 tentang persyaratan kesehatan perumahan, satu orang minimal menempati luas rumah $8 \mathrm{~m}^{2}$. (Kemekes RI, 1999) Berdasarkan hasil analisis multivariat menunjukkan bahwa kepadatan hunian terbukti secara statistik sebagai faktor risiko terhadap kejadian KLB campak anak usia sekolah dasar di Kabupaten Pesawaran dengan nilai $\mathrm{p}=$ $0,036<\alpha=0,05$. Hasil Odds Ratio diketahui 3,971 dengan 95\%CI $=1,092-14,443$ berarti bahwa anak yang tinggal dirumah dengan kepadatan hunian tinggi memiliki peluang 3,791 kali untuk menyebakan kejadian KLB campak. Penelitian ini sejalan dengan Penelitian Nyoman Giarsawan menunjukkan bahwa rumah dengan kepadatan hunian yang tinggi mempuyai risiko menimbulkan kejadian campak 41,25 kali dibandingkan dengan rumah dengan rumah yang tidak padat.(Giarsawan, N., 2014)

Semakin padat penghuni rumah semakin cepat pula udara didalam rumah mengalami pencemaran sehingga penyebaran penyakit pada rumah dengan 
hunian yang padat lebih cepat dibandingkan dengan rumah yang tidak padat. (Sarudji, 2010). Keterbatasan penelitian ini adalah bias recall dan bias informasi.

\section{KESIMPULAN}

Hasil penelitian menunjukkan faktor yang berpengaruh secara bermakna dengan kejadian KLB campak anak usia sekolah dasar adalah riwayat kontak dengan penderita campak, dan kepadatan hunian.

\section{SARAN}

Dinas Kesehatan Kabupaten Pesawaran perlu meningkatkan kerjasama lintas sektor dengan Dinas Pendidikan Kabupaten, Departemen Agama, dan lintas program untuk mendukung dan mensosialisasikan pelaksanaan imunisasi BIAS campak pada anak sekolah. Masyarakat yang mempunyai anak usia sekolah dasar hendaknya memberikan imunisasi campak lanjutan (booster) untuk mendapatkan kekebalan terhadap penyakit campak selama 10 tahun setelah pemberian booster.

\section{UCAPAN TERIMA KASIH}

Ucapan terima kasih penulis sampaikan kepada Kepala Dinas Kesehatan $\begin{array}{lrr}\text { Kabupaten } & \text { Pesawaran, } & \text { Kepala } \\ \text { Puskesmas } & \text { Kedondong, } & \text { Puskesmas }\end{array}$
Kalirejo, dan Puskesmas Bunut serta pihak yang telah membantu dalam penelitian ini, responden penelitian dan para informan. Ucapan terima kasih juga penulis sampaikan kepada keluarga dan semua rekan yang telah membantu dalam penyelesaian penelitian ini.

\section{REFERENSI}

Abbas TC., Charles, T. (2010) Mixed Methodology Mengkombinasikan Pendekatan Kualitatif dan Kuantitatif. Yogyakarta: Pustaka Pelajar.

Adi, P. D. (2012) Penelitian case-control: faktor risiko kejadian campak di kabupaten karangasem tahun 2012. Universitas Udayana.

Budi, D. A. S. (2012) Faktor-faktor yang berpengarub terhadap kejadian campak pada peristiwa kejadian luar biasa campak. anak (0-59 bulan) di Kota Banjarmasin Provinsi Kalimantan Selatan tabun 2011. Unversitas Indonesia.

Casaeri (2003) Faktor-faktor risiko kejadian penyakit campak di Kabupaten Kendal Tabun 2002. Universitas Diponegoro Semarang.

Center of Disease Control and Prevention (CDC) (2018) Measles. Available at: https://www.cdc.gov/measles/hcp/i ndex.html (Accessed: 3 February 2018).

CHIN, J. (2000) MANUAL PEMBERANTASAN PENYAKIT MENULAR. 17th edn. Edited by I NYOMAN KANDUN. Jakarta: CV. Infomedika.

Dinkes Kabupaten Pesawaran (2017) Profil Kesehatan Kabupaten Pesawaram Tabun 2016. Gedong tataam: Dinas Kesehatan Kabupaten Pesawaran.

Dinkes Provinsi Lampung (2017) Profil Kesehatan Provinsi Lampung Tahun 2016. Bandar Lampung: Dinas Kesehatan Provinsi Lampung.

Giarsawan, N., et al. (2014) 'Faktor-faktor yang Mempengaruhi Kejadian Campak Di Wilayah Puskesmas 
Tejakula I Kecamatan Tejakula Kabupaten Buleleng Tahun 2012', Jurnal Kesehatan Lingkungan, 4(2), pp. 140-145.

Kemekes RI (1999) Keputusan Menteri Kesehatan RI No. 829 / Menkes / SK / VII /1999 Tentang Persyaratan Kesehatan Perumahan. Indonesia.

Kemenkes RI (2005) Lampiran Surat Keputusan Menteri Kesehatan Nomor: 1611/MENKES/SK/XI/2005

Tentang Pedoman Penyelenggaraan Imunisasi. Indonesia.

Kemenkes RI (2011) Buku Pedoman Penyidikan dan Penanggulangan Kejadian Luar Biasa Penyakit Mennular dan Keracunan Pangan (pedoman Epidemiologi Penyakit). Edited by K. K. R. Indonesia. Jakarta.

Kemenkes RI (2017) Profil Kesehatan Indonesia Tabun 2016. Jakarta: Kementerian Kesehatan Republik Indonesia.

Lemeshow, S., David W.Hosmer Jr., and S. K. L. (1997) Besar Sampel dalam penelitian Kesehatan. Yogyakarta: Gajah Mada University Press.

Sarudji, D. (2010) Kesehatan Lingkungan. Bandung: Karya Putra Darwati.

Setiawan, I. . (2008) Penyakit Campak. 1st edn. Jakarta: CV. Sagung Seto.

Sugiyono (2016) Metode Penelitian Kuantitatif, Kualitatif, dan Kombinasi (Mixed Methode). Bandung: Alfabeta.

Widagdo (2011) Masalah dan Tatalaksana Penyakit Anak dengan Demam. 1st edn. Jakarta: CV. Sagung Seto.

Williams, F. (2003) Baby Care Pedoman Lengkap Perawatan Bayi. Jakarta: Erlangga. 